\title{
History of Use and Trade of Agarwood
}

\author{
Arlene López-SAMPSON ${ }^{1}$ And TONY PaGe*,2 \\ ${ }^{1}$ College of Science and Engineering, James Cook University, Cairns, 4878, Australia \\ ${ }^{2}$ Tropical Forests and People Research Centre, University of Sunshine Coast, Maroochydore, 4558, \\ Australia \\ *Corresponding author; e-mail: tpage@usc.edu.au
}

\begin{abstract}
Aromatics originating from the resin-infused infected wood of the Aquilaria and Gyrinops genera have distinct and valued fragrances. Resin formation occurs as a response to internal injury and/or infections in the stems of the agarwood tree. The incenses and perfumes that are produced from agarwood have been valued for centuries and used by many cultures for spiritual, opulent, and aphrodisiac purposes. Agarwood is highly revered in the seminal texts of Hinduism, Christianity, Buddhism, and Islam. As early as 1400 B.C.E., agarwood was described as a fragrant product in Sanskrit texts, and in 65 B.C.E., Dioscorides detailed several medical applications for agarwood. Knowledge of human-induced agarwood formation was recorded in China as early as 300 C.E., where it was known that cutting into a tree would lead to a color change in its internal tissues within a year of the injury as a consequence of resin development. There is historical evidence of international trade in agarwood between the producing (tropical southeastern Asia) and consuming (Middle East, India, China, and Japan) regions of the world. Agarwood has been consumed primarily as incense with the burning of wood chips directly or as an important ingredient for powdered incense blends. The aromatic qualities of agarwood are influenced by the species and variety of the two genera, geographic location, its branch, trunk and root origin, length of time since infection, and methods of harvesting and processing. The subtle but numerous variations in agarwood properties led to the development of systems for product classification and description in several consumer countries. This paper reviews the uses and trade of agarwood and its social, political, and economic significance in human history.
\end{abstract}

Key Words:: Agarwood, aloeswood, gaharu, oud, calambac, Aquilaria, history, aromatic plants, fragrant plants, trade.

\section{Introduction}

Aromatics and spices have been a conspicuous element in many cultures and life practices for centuries (Turner 2004) and their rarity, and inaccessibility, often gave them a noble or mystical status. Aromatics and spices have been synonymous with wealth, exclusivity, and luxury, although elites could justify their use as necessary owing to their religious, funerary, medical, and culinary importance (Cobb 2013). Frankincense and myrrh are well-known examples of fragrant resin highly

\footnotetext{
${ }^{1}$ Received 9 May 2017; accepted 12 February 2018; published online 20 March 2018
}

demanded and valued by the people of ancient Egypt, Mesopotamia, Greece, Rome, China, and India (Groom 1981). The earliest recorded use of plant aromatics is found in the four Vedas of ancient India. These texts are proto Hindu, written between 1500-1000 B.C.E., and include descriptions of the already sophisticated use of aromatics. The spiritual significance of aromatic plants was highlighted in these ancient texts and was often referred to as the "spirit of life" (Prâna) (Bloomfield 1897:218) and used as a fragrant smoke for spiritual connections with heaven and as offerings during divine worship (Hymn II. Agni.) (Griffith 1897). The secular use of fragrances was also prominent, where they were used as personal perfumes and to scent the houses of the noble classes (Griffith 1897; Keith 1914) as 
well as their considered natural healing properties (Keith 1914).

The "silk road" was one of the most influential networks of trade routes in ancient commerce (Haq 1968; Liu 2010). Products that were high in value and light in weight, and where a single merchant could bear the load, were traded via the overland route (King 2007). Aromatics were transported along this ancient route along with other high value goods such as silk, porcelain, and spices (Hull 2008). Their trade was associated with the proliferation of religious ideas and considered one of the first expressions of globalization (Foltz 2010). While many hundreds of plant species produce aromatic oils, some, such as agarwood, are particularly revered for their aromatic, historical, and religious significance. Agarwood is the resin-infused fragrant wood (also known as aloeswood, eaglewood, gaharu, oud, chén xiāng, and jinkoh) derived from tropical trees of the genera Aquilaria, Gyrinops, Aetoxylon, and Gonystylis (Thymelaeaceae) (Gunn et al. 2004). Agarwood, along with sandalwood, can retain its fragrance over very long periods when handled appropriately. The longevity of agarwood fragrance permits its storage and long distance trade as a high-value commodity, much in the same way as precious stones and metals (McHugh 2012).

Aquilaria species have been the primary source for agarwood and are distributed eastward from India (Bengal and Assam) to the island of New Guinea and southward from tropical China (Kwantung, Yunnan), to the Lesser Sunda Islands (Hou $1960,1964)$. The resin, is widely used for the production of incense and perfume (essential oils) and for medical purposes (Mohamed and Lee 2016; Rhind 2014). The valuable resin develops and accumulates in the stem and branches of the tree after a process of injury and fungal infection (Bose 1938; Donovan and Puri 2004; Rasool and Mohamed 2016; Sangareswari et al. 2016), but this process occurs in only a few trees in wild populations $(\mathrm{Ng}$ et al. 1997; Paoli et al. 2001). The demand for and trade in agarwood continues today, and with increasing wealth in consumer countries over recent decades, demand exceeds supply (Barden et al. 2000; Chakrabarty et al. 1994; Compton and Ishihara 2006). This has resulted in increased prices (Wyn and Anak 2010), natural resource decline (Zhang et al. 2008), reduction in product quality (Antonopoulou et al. 2010), increasing interest in cultivation (Hoang Ha and Nghi 2011; Page and Awarau 2012; Persoon 2008; Rahman et al. 2015), and developing methods for resin induction (Liu et al. 2013; Mohamed et al. 2014; Persoon 2008). We endeavor to put a historical context to the current interest in agarwood by reviewing its use and trade and examining the reasons for its high esteem and economic value.

\section{Methods}

The review encompasses a range of literature sources including primary sources, research articles, books, and reviews. Classical texts related to religion, trade, aromatics, and pharmacopeias were searched and retrieved from a range of online repositories (Table 1). Contemporary research manuscripts, chapters, and books were searched and retrieved using several bibliographic databases (Table 1). Where possible, preference was given to primary sources and their published translations. The Latin text of Matthioli (1554) relating to agarwood was translated by professional academic Latin translator (Liddy, L.).

\section{Etymology}

The terms agarwood, aloes, and aloeswood are used to refer to the resin-infused wood of species from the four genera: Aquilaria, Gyrinops, Aetoxylon, and Gonystylis. Agarwood, described as aloës in classical literature, has several other names (Table 2) that are derivations of ancient languages and vary according to the languages/dialects of the traders and places where it originated and was used. The many terms by which agarwood are referred to in religious and historic texts add to the complexity when investigating its history. In ancient texts, the word aloes may refer to agarwood, typically as lign or lignum aloes, or products of the arborescent succulent species Aloe, which produces a medicinal bitter paste. The name probably originates in Dravidian $\left(a k^{h} V l-u-\right)$ or Indic languages (i.e., Sanskrit, Prakrit) (Greppin 1988). In Sanskrit, agarwood was known as agäru and aguru which means "non-floating wood" (Miller 1969:35); the Prakrit form is agaru and Pali agalu, all of them synonymous with aloës and agalochon/agallochum. The word agarwood in Greek (agallochum), Hebrew (ahāloth), and Arab (ālūwwa) are loanwords from the Indic names (Greppin 1988; Schafer 1963; Yule and Burnell 1903). In Arabic medico-pharmacological literature, agarwood is reported as $\bar{u} d$ a synonym for gàlu an borrowing through Greek agallochum 
TABLE 1. SOURCES USED TO LOCATE REFERENCE MATERIAL CITED IN THIS REVIEW.

\begin{tabular}{ll}
\hline \hline & \multicolumn{1}{c}{ URL } \\
\hline Repository/database & \\
ABIM: A Bibliography of Indian Medicine & http://indianmedicine.eldoc.ub.rug.nl \\
Brill Online Books and Journals & http://booksandjournals.brillonline.com \\
Christian Classics Ethereal Library & http://www.ccel.org \\
Digital Silk Road Project & http://dsr.nii.ac.jp \\
Gale Literature Resource Centre & http://www.gale.com \\
Google Books & https://books.google.com \\
Hathi Trust Digital Library & https://babel.hathitrust.org \\
Heidelberg Document Repository & http://archiv.ub.uni-heidelberg.de \\
Internet Archive & https://archive.org \\
Internet Sacred Text Archive & www.sacred-texts.com \\
Jstor & https://www.jstor.org \\
National Academic Research and Collaborations Information System & https://www.narcis.nl \\
National Institute of Science Communication \& Information Resources & http://www.niscair.res.in \\
National Library: Ministry of Culture, Government of India & http://www.nationallibrary.gov.in \\
OCLC WorldCat & http://www.worldcat.org \\
ResearchGate & https://www.researchgate.net \\
South Asia Archive & http://www.southasiaarchive.com \\
Sunnah.com The Haddith of the prophet Mohammed at your fingertips & https://sunnah.com \\
The noble Quran & http://quran.com \\
The Roman Law Library & http://droitromain.upmf-grenoble.fr \\
Wisdom Library & https://www.wisdomlib.org \\
Bibliographic database & \\
CabDirect database & https://www.cabdirect.org \\
EBSCOhost databases and digital archives & https://www.ebscohost.com. \\
Google Scholar & https://scholar.google.com.au \\
Science Direct & http://www.sciencedirect.com \\
Scopus & https://www.scopus.com \\
Web of Science (ISI) & https://www.webofknowledge.com \\
\hline
\end{tabular}

(âgáloxon) (Kahl 2011). The main Malay name is kayu găharu or "gaharu wood" a variation of agarul agallochon (Miller 1969). In China, agarwood is referred to as chén xiāng ("the sinking incense," derived from the Sanskrit meaning) (Miller 1969:35), or kilam and bac that means the

TABLe 2. ETyMology of AGARWOOd.

\begin{tabular}{|c|c|c|c|}
\hline Language & $\overline{\text { Agarwood }}$ & Meaning (if any) & Reference \\
\hline Sanskrit & agāru and aguru & $\begin{array}{l}\text { Nonfloating } \\
\text { wood }\end{array}$ & Miller (1969) \\
\hline Prakrit & agaru and Pali agalu & & \\
\hline Greek & agallochum & & Greppin (1988), Schafer (1963), Yule and Burnell (1903) \\
\hline Hebrew & ahạāoth & & Greppin (1988), Schafer (1963), Yule and Burnell (1903) \\
\hline Arab & àlüwwa and $\bar{u} d$ & & $\begin{array}{l}\text { Greppin (1988), Schafer (1963), Yule and Burnell (1903), } \\
\text { Kahl (2011) }\end{array}$ \\
\hline Malay & găharu & & \\
\hline Chinese & $\begin{array}{l}\text { chén xiäng or kilam } \\
\text { and bac }\end{array}$ & $\begin{array}{l}\text { "Sinking } \\
\text { incense" }\end{array}$ & Mathews (1974) \\
\hline Japanese & jinkoh & $\begin{array}{l}\text { "Sinking } \\
\text { incense" }\end{array}$ & Brechbill (2012) \\
\hline Portuguese & aguila or pao d'aguila & & McKenna and Hughes (2014) \\
\hline French & d'aigle & & McKenna and Hughes (2014) \\
\hline English & eaglewood & & McKenna and Hughes (2014) \\
\hline
\end{tabular}


"fragrant plant" (Mathews 1974). In Japan, it is known as jinkoh (also means "the sinking incense") (Brechbill 2012). In European languages such as Portuguese, agarwood is known as aguila or pao d'aguila; in French, the wood is recognized as d'aigle; and in English as eaglewood. The latter is taken from Medieval Latin (aquilaria) which is derived from the Greek (agallochum). The Sanskrit word for incense is known as agarbhatti, which is derived from the word for agarwood (agāru) (McKenna and Hughes 2014).

\section{Agarwood in Religious Texts}

\section{Hindu Texts}

The Sanskrit epic narrative Mahäbhärata (describing the period 1493-1443 B.C.E. of Indian history [Iyengar 2003]) contains the description of the use of fragrance in the context of human pleasure, luxury, and well-being (Rhind 2014). Agarwood was often identified in the text as a display of wealth, a tribute, and a greeting. In the first book of Mahābhārata, the people of the ancient city of Khandavaprastha received distant visitors (Madhava and other tribes) by filling every part of the town "with the sweet scent of burning aloes." (Book 1, Section CCXXIII). Also in Book 1, the use of agarwood for displaying status and wealth was detailed in the description of an amphitheater on the outskirts of King Drupada's capital (Kamapilya), which was "enclosed on all sides with high walls and a moat (and) scented with black aloes and sprinkled all over with water mixed with sandalpaste and decorated with garlands of flowers" (Book 1, Section CLXXXVII). The mansions that surrounded this amphitheater were also "rendered fragrant with excellent aloes," and the "exalted sovereigns" that inhabited the mansions were "possessed with the desire of excelling one another" and "all adorned with the fragrant paste of the black aloe" (Book 1, Section CLXXXVII). The second book contains a detailed description of the mansions of monarchs, which "hung over with garlands of flowers and perfumed with excellent aloes" (Book 2, Section XXXIII). It also details that after the Bharatas people conquered the Mlechchha tribes, the vanquished were made to pay tributes of a great many valuable items including fragrant goods of sandalwood and aloes (Book 2, Section XXIX). The refined use of agarwood and many other aromatics in this text indicates a long association with and veneration for fragrant products.

\section{Christian Scriptures}

Agarwood is referenced several times in the Old Testament of the Christian Bible, firstly where Balaam describes God's vision of Israel and likens their settlements as being "like aloes planted by the LORD" (Numbers 24:6). Also in the Old Testament, the noble and seductive importance of agarwood is presented in Psalm 45:8 where, recounting a king's preparation for marriage, it states that "All your robes are fragrant with myrrh and aloes and cassia." The seductive power of aromatics including agarwood is further described in Song of Songs 4:14 rejoicing the sexual attraction between two lovers, where one praises the other "Your plants are an orchard of every kind of incense tree, with myrrh and aloes and all the finest spices." Similarly, in Proverbs 7:17, there is an invitation by a seductress to her lover: "I have perfumed my bed with myrrh, aloes and cinnamon." In the New Testament, the spiritual significance of agarwood is clearly outlined in the gospel of John (20:3940 ), where Jesus' body was anointed with a mixture of myrrh and aloes following his crucifixion. However, there are some scholars that have argued that the aloe mentioned in this passage referred to medicinal Aloe and not the aromatic agarwood (Crosswhite and Crosswhite 1984; see Greppin 1988 for etymological discussion and uses of the word to describe two different plants; Smith 1993; Smith and Steyn 2004). This may be based on the fact that both myrrh and bitter aloes were used in the embalming procedures of ancient Egyptians (Crosswhite and Crosswhite 1984; Gannal 1840; Grindlay and Reynolds 1986). It is possible that many of the fragrant products used in ancient embalming were applied to obscure the odor of decomposition (Nunnamaker and Dhonau 2015) and/or as a direct connection with worship in the afterlife (Driscoll 1953) and not for the preservation of the body (for which natron [sodium carbonate] performs the most significant role) (Papageorgopoulou et al. 2015; Sandison 1963). The reference to aloes in the New Testament does not describe a complex procedure of embalming, but a simple act of anointment, with Jesus' body wrapped "with the spices in strips of linen." While it is conceivable that agarwood could be described as a spice, a leaf extract from a species of Aloe may be 
considered an herb rather than a spice. Although there are some inconsistencies in the use of the word aloes, it is most likely that the term aloes in both Old and New Testaments refers to the "fragrant spice (not a bitter plant) used as a perfume" (Browning 2010; Zohary 1982). Therefore, the aromatic aloes as described in the Bible and which many authors recognize as from the East Indian tree agarwood (Balfour 1866; Greppin 1988; Harbaugh 1855; McKenna and Hughes 2014) should not be confounded with bitter aloes (Balfour 1866; Rimmel 1865; Schoff 1922; Tielel 1885).

\section{BuddhIST TEXTS}

In several Buddhists texts, there are references to the use of aromatics in religious rituals. For instance, in the Jātaka tales, which are extensive literary works about the Buddha Birth stories ( $\sim$ th century B.C.E.) (Pierce 1969), agarwood is mentioned in Vol VI no. 542. Within the text, the use of fragrance by women is depicted in the story of a King's attempt to enter the world of the gods through ritual sacrifice of his most treasured possessions, including his family. When the sacrifice was prepared, the sons were taken to the sacrificial pit, and there the royal ladies and other women of the town adorned "with aloes, sandalwood, valuable gems and silk robes" paid their respects to the son(s) Canda-Suriya, before going off to the King's sacrifice (Cowell 1907). Both agarwood and sandalwood, in combination with other valuable items, were used as a mark of respect and were already being used as valuable fragrant products during ancient times. In the Mahāyāna Mahäparinirvāna Sütra (Nirvana Sutra), the use of aromatics is mentioned in the introductory chapter that describes a succession of events and teachings that occurred when Buddha was about to enter Nirvana. In one description, the use of fragrant wood in the cremation of Tathaggata's (Buddha) body is mentioned, "people each held in their hands tens of thousands of bundles of such fragrant wood as sandalwood, aloes, goirsa sandalwood, and heavenly wood." Aloe was also used as fuel in stoves to prepare meals for the Buddha and the Sangha (monks). In the Vimänavatthu text ("Stories of celestial mansions"), a collection of 85 poems on the happiness of persons reborn in heavenly realms and on the worthy deeds that led to this reward (Bansal 2006), there are several references to the use of fragrances/ ointments. In poem 35 (7), The Seventh: Sesavati's Mansion (Sesavatīvimāna), during the funeral ceremony of the venerable Captain of Dhamma (Sāriputta), aloe, sandalwood, and similar woods were used as a part of the pyre of a hundred cubits high (Ireland 2005). Bazin (2013) suggested that five natural incense products represented the speech of the five buddhas and included sandalwood, agarwood, pine resin or juniper, camphor, and vetiver root. Fragrant woods have been used as a symbolic relic or ritual deposit within the cavities of valuable sculptures, to transform them into a consecratory object. Leidy and Strahan (2010) report that agarwood was one of several ritual deposits (such as mother-of-pearl, lapis lazuli, rock crystal and silk, and four fragrant woods including rosewood) found within the interior cavity of the 486 C.E. bronze sculpture of Buddha Maitreya. It is clear that the use of fragrant products was an integral part of Buddhist tradition with agarwood among those most valued.

\section{Islamic TeXts}

In the Qur'an, there are references to aromatics but none specifically devoted to agarwood. In the Sürah 55 (Ar-Rahman), the first section describes the abundance of gifts that Allah has bestowed on men including life itself (55:3), speech (55:4), fruits and dates (55:11), and grains, fodder, and fragrant plants (55:12). Inclusion of fragrant plants among this list of gifts so fundamental to life demonstrates the spiritual reverence for these resources. In Sūrah 83:26, it states that those who refrain from fraudulent temptations will be rewarded in Paradise and given access to a range of resources including fragrant musk.

In several Hadith (reports of the words, actions, or tacit approval of the prophet Muhammad) (Lucas 2008), agarwood is referred to as a type of Indian incense (i.e., $\bar{U} d \mathrm{Al}$ - Hindi or aloes). Allah's Messenger was quoted (by Abu Huraira) describing Paradise where, among many wondrous things, agarwood would be used in their censers (incense burner) (Sahih al-Bukhari 3327, Book 60, Hadith 2; USC-MSA English reference Vol. 4, Book 55, Hadith 544). The use of agarwood as a medical treatment was recommended by the prophet $\mathrm{Mu}-$ hammad and was said to contain seven types of remedies, including one for a swollen uvula and another for pleurisy (Sahih al-Bukhari 5692, 5693, Book 76, Hadith 15; USC-MSA English reference Sahih al-Bukhari Vol. 7, Book 71, Hadith 596, 613; Sunan Abi Dawud 3877, Book 29, Hadith 23; English translation Book 28, Hadith 3868). 
Agarwood was also cited as relieving common ailments, and the Prophet said, concerning a Muhrim whose head or eyes hurt: "Let him smudge them with aloes" (Sunan an-Nasa'i 2711, Book 24, Hadith 0; English translation Vol. 3, Book 24, Hadith 2712). Agarwood was used in the important practice of fumigation/ purification where Nafi' reports on Ibn Umar fumigating with aloeswood either by itself or mixed with camphor (Sahih Muslim 2254 Book 40, Hadith 23; English translation Book 27, Hadith 5601).

The prophet Muhammad counsels men and women in the use of fragrance: men should bath and perfume themselves for the Friday sermon at the mosque; women may use perfume at their homes but not at the mosque; and men and women can perfume themselves during sexual intimacy (Thurkill 2009). It is known that the prophet $\mathrm{Mu}-$ hammad preferred the scent of aloes or a combination of aloes and camphor (Book 27 no. 5601) (Sahih Muslim n.d.). The burning of incense in a mosque was practised by Umar the second caliph, which led to the practice becoming commonplace. There is no record of what was burnt, but it is believed that it was aloes by itself or combined with camphor (Ergin 2014).

\section{History of Use and Trade of Agarwood by Region}

\section{Ancient Egypt}

Egyptians were possibly the first civilization to record the use of aromatics with paintings depicting the use and trade of frankincense in the Temple of Deir el-Bahri in Upper Egypt (c 17th century B.C.E.) (Howes 1950). The Eber Papyrus (c 1600 B.C.E.) contains details of the procedures for a substantial number of medicinal preparations many of which contain aromatic plants (Kubeczka 2016). Incense and perfumes were well known by ancient Egyptians as described by Theophrastus (484-425 B.C.E.) and Pliny (23-79 C.E.). Theophrastus described the composition of Egyptian unguents, which were made of several ingredients including cinnamon and myrrh, but agarwood or aloes does not seem to have been used in this period (Lucas 1930). Moreover, there is no record of the use of agarwood in the Egyptian art of embalming although 31 other plant species have been mentioned as used during the process (Baumann 1960; Koller et al. 1998). However, McClintock and Strong (1867) state that the Greek historian Herodotus reported that aloeswood was used by the Egyptians for embalming. Gannal (1840) asserted that the Egyptians used myrrh and bitter aloes (Aloe species) during embalming for their powerful effect in resisting putrefaction rather than exclusively for their fragrant properties. While the timing of the first use of agarwood (aloeswood) and other foreign spices has not been determined, it is clear that aromatics were important products. Many of the aromatics used then were imported and, while the Sumerians were possibly the first civilization to engage in ocean-mediated international trade (3000 B.C.E.), the Egyptians began sailing the Red Sea and the coast of east Africa as early as 2500-2400 B.C.E., trading manufactured goods in exchange for slaves, ivory, gold (from Ethiopia and Somalia), spices (from India via Yemen), and aromatics (frankincense and myrrh from Yemen) (Kearney 2004).

\section{Ancient Greece and Rome}

The people of Ancient Greece may not have made routine use of incense in their rituals (Groom 1981), but the practice was possibly adopted around the 6th century B.C.E., as evidenced by the use of frankincense by the Greek philosopher Pythagoras apparently to help him to prophesize (Dannaway 2010). Also around this time, the Pythagorean brotherhood, a secret, religious, political, and educational society, burned incense in their offerings to the gods (Classen et al. 1994). The Greeks also used incense at public festivals, during processions and at ceremonies for oracles (Groom 1981). It is recognized that Herodotus (c 485-425 B.C.E.) knew about myrrh, frankincense, cinnamon, and other spices as Arabian products traded by the Phoenicians. According to Strabo (c 64 B.C.E. to c 25 C.E.), Eudoxus of Cyzicus made two trips to India (c 120-110 B.C.E.) on behalf of Ptolemy to buy spices and other luxuries (Strabo 1930). Dioscorides in his book Materia Medica (65 C.E.) described several medical qualities of agarwood (Á $\gamma \alpha \lambda \lambda \circ \chi \chi 0 v$ ) and mentioned its use as an incense. Even though Dioscorides describes agarwood as having an astringent and bitter taste, it was used to freshen the breath when chewed or as a decoction held in the mouth. He also writes that a root extract was used to treat stomach complaints and dysentery as well as pains of the lungs and liver (Matthioli 1554). 
The Romans adopted practices and cultural customs (including the use of plants) from other kingdoms brought under their control (i.e., Greek, Egyptian, Phoenician). Among the aromatics used in ancient Rome were rose, lily, sweet flag, narcissus, pepper, cinnamon, spikenard, aloeswood, and fragrant grasses imported from India (Morris 1984). With the annexation of Egypt by the Roman Empire in 30 B.C.E., the Romans controlled many overland and ocean trade routes that directly connected the Mediterranean with Africa, southern Arabia (Egypt), and India (Heldaas Seland 2011; Miller 1969). In 65 C.E., the Roman Emperor Nero expended large amounts of oriental incense to mourn the death of his second wife Poppaea Sabina (Peacock et al. 2006; Rhind 2014). Interestingly, Poppaea Sabina was also embalmed before burial "with spices in the customary habit of foreign kings" despite cremation being the main funerary practice in Rome at the time (Counts 1996). A 3rdcentury C.E. Roman tomb excavated in 1485 contained the preserved remains of a young woman apparently buried in a mixture of "myrrh, aloe and other priceless drugs [sic]" (Lanciani 1892:167). In the 6th century C.E., the Justinian's Digest of Roman law (Book 39) listed 54 valuable articles that were subject to import duty at Alexandria and these included aloeswood (agarwood) (Parker 2008; Scott 1932; Watson 1985).

Roman commercial ties reached China, with reports of Roman traders in 166 C.E. and an envoy in 284 C.E. when they gave a tribute to the Emperor of China comprising 30,000 rolls of thin agarwood (Warmington 1928). A spice merchant, Cosmas Indicopleustes, writes in his Christian Topography (c 550 C.E.) about the imports of silk, aloeswood, cloves, clove-wood, and sandalwood from China and Southeast Asia to Ceylon in the 6th century B.C.E. (1897 translation of c 550 C.E. book). In Cyprus during the 14 th century C.E., agarwood prepared with benzoin (Styrax benzoin) or solid storax (Styrax spp.) was used in 10 medical recipes to treat medical conditions of the ear, eye, skin, muscles, bones, joints, oral cavity and respiratory tract (Lardos et al. 2011).

\section{Middle East}

Agarwood was one of the revered aromatics in the Arab world and is mentioned in many ancient documents with regard to its use in medicine and as a perfume (Zohar and Lev 2013). For example, in al-Kindi's (801-807 C.E.) Book of the Chemistry of
Perfume, five recipes for perfume are written specifically for agarwood and within Ibn M sawahī's (777-857 C.E.) book On Simple Aromatic Substances agarwood was categorized as a principal perfume (most of them imported from other regions) (cited in Zohar and Lev 2013). Two compound perfumes, nadd and ghäliya, were expensive and exclusive and contained musk, aloes, and amber. Ibn $\mathrm{M}$ sawahì also discussed the practice of burying parts of the Aquilaria tree in the ground for up to 1 year as a method to degrade the soft white wood that surrounds the pockets of resin-enriched agarwood (Levey 1961). In a collection of fictional works written during the Abbasid Caliphate known as Arabian Nights, agarwood features in several stories in the context of its use as perfume (pp. 60, 139, 153), incense (pp. 36, 60, 69), in prayer rituals (p. 254), trade (pp. 71, 82), item for tribute (p. 84), status (pp. 484, 532), and construction of a gate and bird cage (pp. 57 and 59, respectively) (Webber 1812). The real-life caliph Harun al-Rashid was an idol in many stories in Arabian Nights, and when he died in 809 C.E., an inventory of his cache included an impressive list of exotic commodities, including 1000 baskets of aloes and many kinds of perfumes (Liu 2010). In Al-Andalus (Muslim Spain between 900-1500 C.E.), local perfumers utilized aromatic substances from both eastern and western origin with musk, camphor, agarwood, ambergris, and saffron classed among the five primary ingredients (Constable 1994). Incense and perfumes were an integral part of imperial life during 16th-century C.E. Mughal empire and based on both ancient then contemporary formulations (Allami 1873). Ain-i-Akbari detailed the ingredients of 12 royal perfume recipes, of which 11 contained either agarwood or its essential oil. Agarwood was also eaten, an experience described as exhilarating. High-quality agarwood was prepared as powder and applied to the skin and clothes (Allami 1873).

Many Arab tribes were involved in trading activities before the Islamic era, with commercial connections with people from North Africa, the west coast of India, Southeast Asia, and China (Hourani 1951; Morris 1984). For example, the Nabateans, a nomadic Arab tribe, were a link between Yemen ("Arabia Felix") and the Mediterranean coast and controlled the trade routes of incense, perfume, and spices between c 25 B.C.E. and c 4 th or 5 th century C.E. (Groom 1981; Zohar 2003). During the Sasanian (Neo-Persian) Empire (224-651 C.E.), vibrant overland and ocean trade routes existed with India and Southeast Asia, with the latter becoming 
increasingly active in trading spices, medicines, and aromatics. A commercial network emerged in the Java Sea, during the 2 nd and 3rd centuries C.E., based on exchange of aromatics, such as agarwood and sandalwood, and spices including cloves (King 2015). An early account of Arab visits to the Indian coastline is found in the book Akhbär al-Sin w'alHind written by Sulayman Tajir (851 C.E.) where he describes Sarandip, an island on the Bay of Bengal, and its main products gold, ruby, aloeswood, and the surrounding sea full of pearls and conch (cited in Islam 2010).

Arabs and Indians were prominent traders in the Indian Ocean between the 7 th-11th centuries C.E., which has been confirmed by archaeological evidence (Flecker 2001; Stargardt 2014). There are records of an Ibādite merchant (Abu-'Ubay-dah) of Umāni origin who went to China during the middle of the 8th century and purchased agarwood (aloes) (Hourani 1951). Much trade between the Arabs and Chinese during this time occurred in the Straits of Malacca particularly for luxury goods including pearls, ivory, coral, glass, fabrics, and a plethora of fragrant products (agarwood, ambergris, benzoin, frankincense, myrrh, ginger, dragon's blood, and rosewater) and spices (cloves, nutmeg, asafoetida) (Chaudhuri 1985). Records from the 13 th century C.E. identify that the trade in aromatics was controlled by Muslim people established in Indonesia (known at that time as Island of the Southeast Asia). In Ibn Baț̣ūtạ's (1304-1377 C.E.) account of his travel to Southeast Asia around 1345, he referred to the region as the source of the incense benzoin and aromatic agarwood (Feener and Laffan 2005).

\section{INDIA}

As with many aromatics, the use and trade of agarwood has had a rich history in India and is described in poetry, trade, educational, and medical manuscripts. Agarwood was also considered to be of great commercial value, and the Arthaśhästra (c 320 B.C.), a treatise on economic policy, governance, military affairs, and international relations in the Mauryan Empire (Liebig 2014), provides details of important natural and traded products (Zumbroich 2012). The text states that aromatics featured as one of the "precious articles to be received in the treasury," with aloeswood and sandalwood being described as the finest aromatics (Zumbroich loc. cit.:60). In the Arthaśhästra, agarwood and other aromatics were also subject to a state tax at one- tenth or one-fifteenth of the sale price of the products.

In the texts of Kämasūtra (3rd century C.E.), Nägarasarvasva, and other treatises dealing with pleasure (end of the 1st millennium C.E.), the use of perfumes and unguents (among other esthetic practices) was essential for the sensual experience (Ali 2011). In the Kämasūtra Gandhayukti, the technique of making perfumes was one of the 64 arts to be learned by men and women (Penchala et al. 2008). The Gandhasara (c 500-1000 C.E.) suggests that aromatics lead to the attainment of the three aims of human life, namely "religious merit, worldly prosperity and sensual enjoyment" (Rhind 2014:109; Worwood 2013).

Evidence of the importance of aromatics in Tamil, India, is presented in the poetic work of Cilappatikäram (c 5th century C.E.), which mentions that scent of sandalwood, aloeswood, musk, and civet emanating from the city of Madurai (capital of the Pandya kingdom) could be detected by travelers from a distance away (Atikal 1994). The Harshacharita is a fictionally embellished biography of the Indian emperor Harsha written by the Sanskrit writer Banabhatta. In Chapter VII, an offering to a king was made, and among a plethora of valuable gifts were "volumes of fine writing with leaves made from aloe bark, thick bamboo tubes containing mango sap and black aloes oil, and bundles contained in sacks of woven silk and consisting of black aloe dark as pounded collyrium" (Cowell and Thomas 1887:243). Under Sassanid rule, agarwood was sent among other valuable items as tribute from India to Persia during the reign of Kisra Anushirwan (531-579 C.E.) (Masudi 1877). While it is not unusual to find agarwood included in the long lists of valuable items as offerings to important people, the use of the bark of agarwood for writing demonstrates an alternative use for this tree. Plant aromatics, including agarwood, were the ingredients widely used in the making of fragrances in India in the late 1st millennium C.E. (McHugh 2011; Penchala et al. 2008).

India has been of commercial interest to many civilizations since ancient times. Repeated visits to India by Greek traders were reported following the original voyages of Herodotus (c 485-425 B.C.E.). During Roman times, when Alexandria was central to regional commerce, commodities from India, Arabia, Egypt, and Ethiopia converged in the city (Banerjee 1921). The products traded from India during the Roman period were varied and included silk, precious stones, spices, and aromatics including 
agarwood (Prasad 1977). Agarwood was known to be sourced from upland regions around the Ganges watershed (Allami 1891; Matthioli 1554) and possibly imported from Tenasserim (west coast of Malay Peninsula) and Sumatra (Yule 1871). Eusèbe Renaudot translated a 9th-century C.E. Arabic travel account that included a description of agarwood occurring naturally in Sri Lanka (Harris 1744). Merchant ships, using the monsoon current to ply the coast of India, facilitated the trade of luxury products and an increase in the importation and consumption of eastern goods in Rome (Warmington 1974). Benjamin of Tudela, who traveled to India in the 12 th century C.E., mentioned India, as an exporter of silk cloth, cinnamon, ginger, and other sorts of spices found in abundance in south India (Samaddar 1911). Sandalwood, agarwood, musk, camphor, and saffron persist as central ingredients in Indian perfumery from the 9th-11th centuries C.E. (McHugh 2012). During the travels of German adventurer Johan Albrecht de Mandelslo through Surat in India during the 1630s, he recorded that wild agarwood was sourced from, among other places, Java, Malacca, Sumatra, and Cambodia. He recorded that wild agarwood was used for the cremation of Indian priests and princes (Harris 1744) and thus confirming its high status in Indian society at this time. In India, during the 1500s C.E., agarwood, musk, and ambergris were used for flavoring betel nut preparations (de Orta 1891; Tielel 1885). In the 19th century, the extraction of agarwood was a customary activity in various parts of Assam, with much of the product exported from Calcutta for re-export to Turkey, Arabia, Persia, and Europe (CSIR (India) 1953). During the early 20th century, China became a more prominent export market for Indian agarwood (CSIR (India) 1953).

In both India and China, the bark from agarwood was used to manufacture paper (Borris et al. 1988) from as early as 284 C.E. when it was described as being strong and tough. Even though the bark was soft, it did not disintegrate when immersed in water and had a yellow clay color with "markings in it like fish roe" (Ju-Kua 1911:205). The paper was also described as strongly scented (Ju-Kua 1911; McLaughlin 2008), although it is not clear if this scent was associated with the natural aroma of the bark or from added fragrances.

\section{ChInA}

The development of trade routes linking the Mediterranean to East Asia in the early centuries C.E. marked the start of a long period of trade between north India and China. Luxury goods, including coral, pearls, precious stones, glassware, incense, and perfume from India, were traded along these routes for Chinese silk (Liu 1994). The first use of incense in China has been placed around the 1 st century C.E. and is considered as a direct influence from Buddhist Indian culture (King 2007). Records of incense/aromatic use can be found in the oldest known official pharmacopeia (Hsin Hsiu Pen Ts'ao c 659 C.E.), which contains a list of prominent components (aloeswood, frankincense, cloves, patchouli, elemi, and liquidambar). In the 3rd century C.E., aromatics from Southeast Asia were considered sophisticated luxuries for use by the Chinese ruling elite. The governor of Jingzhou in the late 3rd century was reported to have finely powdered agarwood scattered over an ivory bed. His favored serving girls were requested to step on it, with rewards (pearls) for those who left no footprint and punishments (ordered to lose weight) for those who disturbed the powder (Gungwu 1958). In one of the first known written floras on subtropical Asian plants (Nan-fang Ts'au-mu Chuang written around 300 C.E.), the knowledge of humaninduced agarwood formation was discussed with a brief description that cutting into the tree would bring about a change in color of the internal tissues ("root, stem, branches and joints") within a year of the injury as a consequence of resin development (Ju-Kua 1911). By the 4th century C.E., aloeswood and cardamom were being imported from Vietnam and Cambodia to China (Gungwu 1958; Keay 2006). These imports, and tributes of agarwood from Vietnam (Dai Viet and Champa), continued well into the period of the Song Dynasty (9601279 C.E.) (Shiro 1998), a time when agarwood was recorded by Marco Polo to be abundant in both southern Vietnam (Champa) and eastern Indonesia (Yule 1871).

Schafer (1963) provides a detailed account of exotic products imported into China during the three centuries of the T'ang Dynasty (A.D. 618907). These include many plant products, animals, and minerals, as well as spiritual and manufactured goods. Over this period, aromatics were sourced from a large number of native plants as well as imported products, although the latter were always more valuable and coveted (Schafer 1963). Schafer 
describes that "women and men of the upper classes lived in clouds of incense and mists of perfume" (p. 155). The emperor Hsuan Tsung (847 C.E.) promulgated a decree, which included a number of conditions including one that he would consider memorials and petitions only after he had washed his hands and burned incense. Schafer (1963) described how a Chinese prince of the 8th century C.E. would speak to guests only after he had aloeswood and musk in his mouth (although the text is not clear as to whether it was the prince or the guest with the fragrant mouth). Extravagance is also found in Han His-tsai practice of burning incenses in his garden (already full of flowers) to produce an exquisite blend of aromas: aloeswood with bramble, musk with magnolia, and sandal with michelia (Schafer loc. cit.). A "gallery" built of agarwood by one of Hsuan Tsung's ministers containing sandalwood railings and walls rendered with the fragrance of musk and frankincense was used as an extravagant display of wealth and power (Schafer loc. cit.:160).

Aromatics were also discussed in Ch'ing $i$ lu (translated as "records of unworldly and strange things") compiled by T' ao Ku. The incense seal, a sophisticated form of incense developed during the 8th century C.E., burned during Tantric Buddhist rituals, is believed to be crafted mainly with agarwood (Bedini 1994:26). Agarwood is also one of the 24 ingredients required in a recipe for an incense seal for use in Buddhist worship (Kao Lie, Tsun sheng pa chien, c 1570 quoted in Bedini 1994:90). The incense seal also served as time measurement in both China and Japan, where incense tablets or sticks were marked with the time divisions at certain intervals and put in a container or tray where the seal-character (shape of the incense trail when burned) would form. The burning of the tablet or stick would indicate the passage of the time (Bedini 1963). The prominence of agarwood in these important spiritual and time-keeping products is further evidence of how it was revered in China.

In the official pharmacopeia of T'ang, agarwood, frankincense, cloves, patchouli, elemi, and liquidambar were the six essences most used by blenders of aromatics (Schafer 1963). Aromatics were a recurrent subject in literary works (Bedini 1994). For instance, in poetry, the phrase "hundred-blend aromatics" (a paste formed with several ingredients, including resins such as agarwood and sandalwood) is commonly used (Bedini loc. cit.:29). Agarwood is also reported as being used to perfume buildings and to scent the garments of courtesans (Schafer
1963). Agarwood had a prominent status in T'ang period medicine and was prepared as an ointment for external applications as well as a decoction in wine to treat many different internal ailments, to expel evil spirits, and to cleanse the soul. Agarwood had a spiritual dimension in China, and of the many tributes provided to emperors of the T'ang, one includes a detailed description of a "mountain of the myriad of Buddha," which was a 10-feet (ft)high carving of agarwood adorned with jewels comprising a verdant mountain scene that included a setting of buildings and images of all the Buddhas (Schafer 1963:38). In 871 C.E., the religious significance of agarwood was demonstrated when Emperor I Tsung granted high seats to the monks of An-Kuo Temple that were $20 \mathrm{ft}$ tall, framed in sandalwood and agarwood, and used by lecturers on the sutras (Buddhist aphorisms) (Schafer 1963).

Vibrant international trade occurred during the last four centuries of the 1 st millennium C.E., as a result of the emergence of a unified China under the Sui Dynasty (581-618) and its peaceful expansion under the Tang Dynasty (618-907) and the rise of the Islamic dynasties of Umayyad of Damascus (661-750) and Abbasids (749-1258) (Villiers 2001). This, combined with advances in shipbuilding and navigation, opened up ocean trade between China, India, and Arab centers in the Middle East (Kearney 2004; Villiers 2001). Persians and Arabs sailed to Canton where they traded a wide range of aromatic goods for porcelain, silk, and copper coins, and T'ang goods spread as far west as Constantinople (Kearney 2004). In 916 C.E., Abü Zaid wrote that the center of the trade in agarwood, sandalwood, and camphor was Kaläh (believed to be either on the west coast of the Malay peninsula or Tenasserim Coast), which was a protectorate of the Sri Vijaya in Sumatra (Villiers 2001).

By the late 11th century C.E., large volumes of agarwood and sandalwood were traded into China by Southeast Asian merchants: 2950 kg (4890 catty) of aloeswood was sent from Jiaozhi (northern Vietnam) in 1063 (Villiers 2001). Stargardt (2014) reports that Chinese merchants were still taking advantage of the lucrative trade in agarwood in Southeast Asia during the mid to late 12th century C.E. and were exploiting natural sources in the Kra Ecotone of south Thailand in exchange for highquality ceramics. Abundant sources were also found in the Malay Peninsula, Sumatra, and Java (Yule 1871). In the late 12th century C.E., Marco Polo wrote about the wealth of the port city of Quanzhou (Zaiton) derived from the duties paid on imported 
goods including $40 \%$ tax on items such as agarwood (Yule 1871). In the beautifully preserved Quanzhou wreck of a 13th-century C.E. Chinese sailing junk (excavated in 1973), the most abundant cargo was incense wood which was discovered in 12 of the 13 holds and weighed $2400 \mathrm{~kg}$. Other exotic goods were inventoried, including small quantities of (possibly Arab) frankincense (6.3 g), ambergris from Somalia, and dragon's blood (Stargardt 2001). Trade routes for agarwood in China may have been widespread at this time, with Marco Polo reporting that agarwood was used in western China during complex rituals for healing the sick (Yule 1871), although the source of the product was undefined.

Chinese trade presence in Southeast Asia and the Indian Ocean was also prominent during the Ming Dynasty of the 1400s. At this time, China had a significant navy and a large number of private merchant ships trading with Korea, Japan, Southeast Asia, India, and east Africa. For example, the Chinese imported a diversity of plant products for medical purposes from Sumatra, and these included pepper, ginger, medicinal herbs, camphor, frankincense, and sulfur (Kearney 2004). From Jidda (Red Sea Port in Saudi Arabia) and Dhufar (Oman), the Chinese purchased frankincense, myrrh, aloe (possibly bitter aloes), and medicines (Kearney 2004). Contact with western merchants is reported throughout the history of China, with records as early as 166 C.E. (Warmington 1928) continuing through the T'ang Dynasty (618-907 C.E.), when Greek, Roman, Arab, Indian, Persian, and Japanese merchants frequented the empire, and then with direct trade with Europeans in the 16th century (Fitzgerald 1961).

Medical preparations containing agarwood are featured in Li Shizhen's 1573 C.E. compendium Compendium of Materia Medica (Ben Cao Gang $M u$ ), which is recognized as the first comprehensive medical publication on traditional Chinese medicine (Unschuld and Zhang 2014). Agarwood prepared as pills, decoctions, and plasters in combination with a myriad of other ingredients was attributed to having a range of positive health effects including stimulant, carminative, aphrodisiac, antirheumatic, antimalarial, analgesic, deobstruent, tonic, and diuretic properties (Smith and Stuart's 2003 translation of Shizhen's 1578 text).

\section{JAPAN}

The use of aromatics in Japan began during the 6th century C.E. and, as with China, coincided with the arrival of Buddhism. The first written record of the use of fragrant wood is found in the Nihongi (Chronicles of Japan) when Emperor Kimmei (549-571 C.E.) commissioned the carving of two Buddhas in 553 C.E. from camphor wood that was found floating in the sea by one of his noble attendants. The first Japanese written record of agarwood was also reported in the Nihongi when, in 595 C.E., a large piece of agarwood drifted ashore on the island of Awaji. The islanders noticed in wonder that it produced a strong fragrance when used as firewood, and later presented an unburnt piece to Empress Suiko (Aston 1896). Early mixtures of aromatics burned in Japanese Buddhist ceremonies included jinkoh (the best incense: agarwood), sandalwood, cloves, cinnamon, and camphor. When Emperor Tenji (671 C.E.) fell ill, during his final year, he sent a tribute to the Buddha of Hōko-ji (Kyoto) of a range of valuable items including agarwood and sandalwood (Aston 1896).

A recurrent story about incense use in Japan refers to a highly revered and large piece of agarwood known as Ranjatai, which was a gift from the China Court to the Emperor Shômu (724-748 C.E.) (Bedini 1963; Brinkley 1902; McKenna and Hughes 2014). Small pieces have been removed from Ranjatai over time but only during prosperous occasions or for special tribute (Bedini 1994). Ranjatai continues to be located at the Shōsōin repository in Nara and is exhibited periodically. During the Nara period (710-794 C.E.), the burning of incense became a secular activity (Gatten 1977). Kneaded incense blends imported from T'ang, China (618-907 C.E.), contained aloeswood, sugar, and plum meat and were highly prized in Japan (Aston 1896; Schafer 1963).

Incense ceremonies (kōdō) began to emerge during the Heian period (794 to 1185 C.E.) and were one of the emblematic practices of aristocrats where aromatics were at the center of focus of the ceremony. In the ceremony, participants discriminated and judged the qualities of different aromatics, including local products pine and cedar and exotics such as agarwood, sandalwood, cinnamon, and cloves (Brinkley 1902; Morita 1992; Morris 1984). During the period 833-850 C.E., Japanese aristocrats ceased importing incense from China and began the manufacture (and blending) of their own incenses. Prince Kaya formulated the famous Six Scents (described in the Kunshü Ruishō c 12th century C.E.); all the Six Scents are compounded of the same six elements in different ratios: aloes, cloves, seashells, 
amber, sandalwood, and musk. A characteristic seventh ingredient defined the final scent, for example, if frankincense was added, the scent created was known as the Black incense (Gatten 1977).

\section{EUROPE}

European nations began to influence the international trade of spices from the beginning in the 14th century C.E. The Portuguese, followed by the Spanish and then, by the end of the 16th century, the Dutch, French, and English all traded spices with India and east Asia and sold them in lucrative European markets. Matthioli (1554) provided insights into the origins, harvesting process, product classes, fragrant properties, and medical applications of agarwood. In the 16th century C.E., the best agarwood available in Europe was sourced by the Portuguese from the port of Calcutta in India, Taprobana (presumably trading posts in Sri Lanka), and other neighboring ports (possibly Java where agarwood was abundant). The agarwood was brought back as tree trunks and not necessarily burnt, but rubbed with the hands to liberate its fragrance. Portuguese and French traders also sourced agarwood from southern Vietnam to trade in China, India, and the Middle East from the 16th-18th centuries C.E. (Chin-keong 2017; Lach 1905; Pires 1944). The French merchant JeanBaptiste Tavernier wrote in the mid-1600s C.E. that the Portuguese of Goa sent piece of agarwood measuring $6 \mathrm{ft}$ in length as a tribute to the Emperor of Japan (Harris 1744). This demonstrates Europeans were aware of the reverence that Asian aristocracy had for agarwood. Interestingly, Matthioli (loc. cit.:44, $\ln 7$ ) writes that agarwood was valuable "everywhere" except for the places from where it was sourced. While much is written about the European trade of spices including tea, cinnamon, cloves, pepper, and nutmeg (Freedman 2008; Turner 2004), there is less consideration of European involvement in the trade of incense products including agarwood. In a three-volume 1942-page account of the British East India Company between 1600-1708 (Bruce 1810), pepper was cited over 250 times, whereas little to no references about fragrant products like agarwood (none), camphor (none), or sandalwood (once in vol. 1 p. 269) were made. Chaudhuri (1978) described that, while pepper and calicoes were the bulk of imports of the East India Company in the 17th century, other commodities including gum resins (aloes, myrrh, olibanum) were still listed in the import records. Incense blends of the West were distinct from those of the East. In the West, the ingredients commonly used for incenses were frankincense, myrrh, galbanum, and onycha (Schafer 1963).

\section{Historical Agarwood Grades and Quality}

Grading is important for defining products based on their market qualities and influences price determination and trade transparency (Giovannucci and Reardon 2000; Ismail et al. 2015). The Portuguese apothecary Tomé Pires visited Malacca and India between 1512-1515 C.E. and suggested that there was as much variation in the qualities and prices of agarwood as there was between gold and lead (Pires 1944). Systems for grading of agarwood were documented in China during the Song Dynasty (9601270 C.E.) and Japan during the Ashikaga shogunate (16th century C.E.). Basic descriptions for agarwood in India (320 B.C.E.) and product traded by Europeans were also recorded in the 16th century C.E.

\section{Middle Eastern Descriptors}

The Ain-i-Akbari is an administrative account of the 16th-century C.E. Mughal empire during emperor Akbar's reign (1542-1605) (Allami 1873). While much of the territory of the Mughal empire was across the Indian subcontinent, it reflects a Persian Muslim culture akin to parts of modernday Middle East. The Ain-i-Akbari contains detailed accounts of agarwood (' $U$ 'd) products, preparation, and grades. Initial processing of agarwood took place through burial of the tree to promote the rotting of the wood that surrounds the pieces of agarwood. The best quality was described as black, heavy not fibrous, and may be easily pounded. This best quality settles at the bottom when placed in water, while poor quality floats. Agarwood was also graded according to 12 different kinds, which in order of quality were known as Mandali, Jabali or Hindí, Samandúri, Qumárí, Qáquli, Barri, Qit'i, Qismúrí (Chinese), Jaláli, Máyatáqí, Lawáqi, and Ritali. While descriptors were provided only for Samanduri (gray, fatty, thick, hard, juicy, without the slightest sign of whiteness, and burns long) and Qismúr' (wet and sweet), the many kinds of ' $U$ 'd reflect the sophisticated accounts of perfume preparation (Allami 1873). 
The oil produced from ' $U$ ' $d$ was known as Chiwah, which was also an important product used in aromatic perfumes. A detailed description of processing $U^{\prime} d$ into Chúwah using water and heat was provided in the Ain-i-Akbari, which can yield between 2.5-18.7\% essential oil (one sér of ' $U$ 'd yields between 2-15 tólahs of Chúwah). Actual weights of the sér and tólah varied between geographic regions but relative proportions were maintained such that a sér equated to 80 tólah) (Allami 1873; Prinsep 1834). The aromatic properties of the Chuwah produced in this way could be improved through washing in water as well as further aging. Chuwah was adulterated with sandalwood or almond oil by some traders trying to cheat people (Allami 1873), confirming agarwood was more valuable than sandalwood at the time. Recorded prices for agarwood were at 2.5 to 11 times greater than sandalwood for minimum and maximum prices, respectively. Agarwood was 2 Rupee to 1 Mohur per sér (equating to 80-600 Rupee per maund [ $-37 \mathrm{~g}]$ ) and sandalwood 3255 Rupee per maund (Allami 1873).

\section{INDIAN DESCRIPTORS}

Agarwood is described in the Arthash ästra (c 320 B.C.E.) as "heavy, soft, greasy, smells far and long, burns slowly, gives out continuous smoke while burning, is of uniform smell, absorbs heat, and is so adhesive to the skin as not to be removable by rubbing" (Shamasastry 1915:107). Three distinct agarwood product descriptors are provided in the Arthashisstra: (1) Jongaka is black or variegated black and is possessed of variegated spots; (2) Dongaka is black; and (3) Párasamudraka is of variegated color and smells like cascus (?) or like Navamálika (jasminum) (Shamasastry 1915:106). Johan Albrecht de Mandelslo described that the quality of agarwood in Surat was determined by its weight and color (which must be brown) and that an oil can be seen on the wood when it is burnt (Harris 1744). During his voyage to India in the 1500 s C.E., John Huyghen van Linschoten described the best agarwood was known as calamba (sourced from Malacca), which was dark in color and rich in fragrant resin (Tielel 1885). Other types of agarwood were described as palo daguilla (also from Malacca) and aguilla braua ("wild agarwood") sourced from Ceylon (Sri Lanka), the latter of which was used in the funeral pyres of nobles (Tielel 1885).

\section{Chinese Grades}

Yoshnobu (1983) confirmed that during the Song Dynasty (960-1270 C.E.), the Chinese were eager to obtain spices and incense from abroad, and agarwood was the most preferred among incense woods. Ju-Kua (1911) published an interpretation and annotation of the Song Dynasty literary account "Record of Foreign Nations" (Chu-fanchi) by Chau Ju-Kua. It contains detailed descriptions of China's trading partners and commodities during this time, including insights into the sources and product qualities of agarwood (Table 3). Agarwood was acquired from a variety of east Asian sources, including northern (Kiau-chi) and southern (Chan-chöng) Vietnam, Cambodia (Chön-la), Thailand (Töng-liu-mei), the Malaysian Peninsula (Tanma-ling, Ling-ya-ssï (kia), and Fo-lo-an), eastern Sumatra (San-fo-tsi), Java (Shö-pos), Borneo (P'o-ni), and Hainan (Hai-nan) as well as being traded with the Arabs $(T a-s h i)$. The aromatic qualities of agarwood traded during the Song Dynasty were strongly influenced by type (possibly variety or species) (Table 3), regional source (geographic location), biological source (branch, trunk, roots), and maturity ("fresh" vs. "ripe"). The maturity of agarwood products was not necessarily related to the age or size of the tree, but to whether the agarwood was harvested from a living (fresh—shöng) or decayed (ripe-shóu) branch or tree. Freshly harvested agarwood was described as having a lasting fragrance and superior to the often "singed" aroma of ripe agarwood. The ripe agarwood has parallels to two grades in current Chinese trade described as being formed in broken branches or from a tree that has been buried and decomposed under aerobic (tu chen) or anaerobic/swampy (shui chen) conditions (Mohamed and Lee 2016). While the aromatic qualities were of greatest importance during the Song Dynasty, the shape of a given piece of agarwood was also classified according to whether it resembled a rhinoceros horn (si-kio), swallow (yenk'ou), "aconite" (possibly Aconitum species) roots $(f u-t z i)$, and a shuttle (possibly the device used in weaving to carry the weft) (so).

Five types of agarwood were described (and two others cited: P'ong-lai [north Vietnam and Hainan], Chö-ku-pan- [Hainan]), which approximates a combination of different species, product type, and degrees of maturation. Agarwood originating from the more northerly origins (Thailand, Cambodia, Vietnam, and Hainan) were considered superior from those from Indonesia, which were 
TABLE 3. NAMES AND POSSIBLE REgION OF ORIGIN OF THE SIX TYPES OF AGARWOOD IN CHINA DURING THE 10TH TO 13TH CENTURY C.E.

\begin{tabular}{|c|c|c|c|c|c|c|}
\hline Type region & $\begin{array}{c}\text { Chön- } \\
\text { hiang }\end{array}$ & $\begin{array}{l}\text { Tsién- } \\
\text { hiang }\end{array}$ & $\begin{array}{c}\text { Su-/Chan- } \\
\text { hiang }\end{array}$ & $\begin{array}{c}\text { Huang-shóu- } \\
\text { hiang }\end{array}$ & $\begin{array}{c}\text { Shöng- } \\
\text { haing }\end{array}$ & $\begin{array}{r}\text { Pong-lai- } \\
\text { hiang }\end{array}$ \\
\hline North Vietnam (Kiau-chi) & $\mathrm{x}$ & & & & & $\mathrm{x}$ \\
\hline South Vietnam (Chan-chöng) & $\mathrm{x}$ & $\mathrm{x}$ & $\mathrm{x}$ & & $\mathrm{x}$ & \\
\hline Cambodia (Chön-la) & $\mathrm{x}$ & & $\mathrm{x}$ & $\mathrm{x}$ & $\mathrm{x}$ & \\
\hline Hainan (Hai-nan) & $\mathrm{x}$ & $\mathrm{x}$ & & & $\mathrm{x}$ & $\mathrm{x}$ \\
\hline Thailand (Töng-liu-mei) & $\mathrm{x}$ & $\mathrm{x}$ & $\mathrm{x}$ & & & \\
\hline Kuantan, Malaysia (Tan-ma-ling) & & & $\mathrm{x}$ & & & \\
\hline Langkasuka, Malaysia (Ling-ya-ssi-(kia)) & & & $\mathrm{x}$ & & $\mathrm{x}$ & \\
\hline Beranang, Malaysia (Fo-lo-an) & & & $\mathrm{x}$ & & & \\
\hline Eastern Sumatra (San-fo-tsi) & $\mathrm{x}$ & & $\mathrm{x}$ & & & \\
\hline Java $\left(S h \ddot{o}-p^{\circ} o\right)$ & $\mathrm{x}$ & & & & & \\
\hline Borneo $\left(P^{c} o-n i\right)$ & & & & & $\mathrm{x}$ & \\
\hline Arabs $(T a-s h i)$ & & & & & & \\
\hline
\end{tabular}

used regularly for medicinal rather than aromatic purposes (Ju-Kua 1911).

Of all the types described, Chön-hiang was recognized as being superior in density (with a high resin content and sinks in water) and fragrance to all other agarwoods and sourced from the heartwood and branch nodes. Tsiénhiang was similar in fragrance, more fibrous, less dense, and considered of inferior quality to Ch\%onhiang. Su- and Chan-hiang are two closely related products, with the former regarded as superior incense, and the qualities of both often influenced by maturity (i.e., fresh or ripe). Huang-shóu-hiang is described as ripe (shóu) yellow (huang) agarwood, which can sometimes be hollow and typically root material. Shöng-hiang describes the "fresh" and possibly underdeveloped agarwood extracted from young branches. The reason that it may be considered immature is that the quality of the agarwood from branches was considered to improve with the thickness of the bark over the agarwood: low-quality shöng-hiang (with a bark thickness of $-7.5 \mathrm{~mm}$ ), moderate-quality Tsién-hiang ( $-12 \mathrm{~mm}$ bark), and high-quality Chön-hiang ( $-25 \mathrm{~mm}$ bark).

In Li Shizhen's seminal Compendium of Materia Medica (Ben Cao Gang Mu), a simplified system of grading agarwood was described based on its density (sinking properties in water). Three grades were defined: shui chen (total sinking), zhan xiang (partial sinking), and huang shu xiang (does not sink [floats]), with the depth of sinking positively related to the concentration of resin (wood density) contained within the agarwood (Mohamed and Lee 2016; Shizhen 2003).

\section{Japanese Grades}

The popularity of agarwood in Japan increased in the late 16th century C.E., and connoisseurs appointed by Shoguns Ahsikaga Yoshimasa defined the fragrances of six recognized types of jinkoh (Table 4). Some elements/components of this system are still used today. At this time, the six agarwood types were both rare and costly and mainly traded to serve as gifts to distinguished individuals (Bedini 1994). To this day, agarwood is held as sacred in the Kareki Shrine located in the northwestern shore of Awajishima (Whelan 2014).

\section{EUROPEAN Descriptors}

Identification and descriptions of agarwood were largely based on foreign classifications. In 16thcentury C.E. Europe, Matthioli (1554) outlined several agarwood grades. The highest quality was black agarwood with a sometimes mottled color, heavy, dense, hard, and full of resin that burns reluctantly when ignited. Second-grade agarwood was known as Mondunum (named after the Indian town in Model), although a description is not provided. Third grade was referred as Seificum which is not considered to be dark but is surpassingly strong, full of resin, and defined as sinking in water (resin content is positively associated with wood density). The last grade described was Alcumericum, which was various shades of black (with no white) and very resistant to flame. Matthioli's description of two agarwood grades being difficult to burn does not reflect Chinese or Japanese descriptions and may 
TABLE 4. NAMES, DESCRIPTIONS, AND POSSIBLE ORIGINS OF THE SIX KINDS OF AGARWOOD (JINKOH) USED IN JAPAN IN THE 16TH CENTURY C.E. SOURCE: MORITA (1992).

\begin{tabular}{|c|c|c|}
\hline $\begin{array}{r}\text { Jinkoh } \\
\text { type }\end{array}$ & Description (16th century) & $\begin{array}{l}\text { Possible } \\
\text { geographical } \\
\text { origin }\end{array}$ \\
\hline Kyara & $\begin{array}{l}\text { A gentle and dignified smell with a touch of bitterness. The fragrance is like an aristocrat in } \\
\text { its elegance and gracefulness. }\end{array}$ & Vietnam \\
\hline Rakoku & $\begin{array}{l}\text { A sharp and pungent smell similar to sandalwood. Its smell is generally bitter and reminds } \\
\text { one of a warrior. }\end{array}$ & Thailand or Laos \\
\hline Mankaka & $\begin{array}{l}\text { Smells light and enticing changing like the mood of a woman with bitter feelings. None of } \\
\text { the } 5 \text { qualities (tastes) are easily detectable. The fragrance is of good quality if it } \\
\text { disappears quickly. }\end{array}$ & Malacca, Malaysia \\
\hline Manaban & $\begin{array}{l}\text { Mostly sweet. The presence of sticky oil on a mica piece is often a sign that the fragrance is } \\
\text { manaban. The smell is coarse and unrefined, just like that of a peasant. }\end{array}$ & Unknown \\
\hline Sumotara & $\begin{array}{l}\text { Sour at the beginning and end. Sometimes easily mistaken for kyara, it has something, } \\
\text { however distasteful and ill-bred about it, like a servant disguised as a noble person. }\end{array}$ & $\begin{array}{l}\text { Sumatra, } \\
\text { Indonesia }\end{array}$ \\
\hline Sasora & $\begin{array}{l}\text { Cool and sour. Good-quality sasora is mistaken for kyara, especially when it first begins to } \\
\text { burn. Sometimes it is so light and faint that one may think the smell has disappeared. It } \\
\text { reminds one of a monk. }\end{array}$ & Assam \\
\hline
\end{tabular}

represent products available in Europe, products that no longer exist, and/or an erroneous description.

Matthioli (1554) reviewed the works of physicians Serapion of Alexandria (early 3rd century C.E.), Simeon Sethi (11th century C.E.), Nicholas Myrepsos ("Dynameron" late 13th century C.E.), Chealfetebeni (unknown authority), and Leonhart Fushs (early 16th century C.E.). The first four wrote about the practice of burying agarwood in the ground for a period after cutting from the tree and prior to sale. In a similar description to Ibn M sawahī's (777-857 C.E.) (Levey 1961), Chealfetebeni suggests that the ideal period of burial was 1 year to promote the decay of the surrounding nonfragrant wood and liberate the agarwood pieces. Serapion and Sethi indicated that agarwood is more fragrant after a period of burial in the earth in comparison with the "raw" unburied wood procured directly from the tree. This preference for buried agarwood in Europe contrasted with the Chinese preference of fresh over ripe agarwood (see section "Chinese Grades"). However, Myrepsos suggests there is no need for burial of the highest-quality agarwood, but lesser qualities can be improved through the processes associated with burial (Matthioli loc. cit.).

During the early 1500s C.E., Pires (1944) described that the best agarwood sourced from southeast Vietnam (Champa) was known as calambac, while the type exported to Portugal was known as guaro. In the mid-1700s, Pierre Poivre described three grades of resinous agarwood from southern Vietnam (Chochinchina) based on their maturity and resin concentration: (1) Khi nam [ $k$ nam $]$ (in French calembat) is of the highest quality and is sourced from the "heart" of the tree and is so resinous and soft that it can be scraped with the human fingernail; (2) tlam hieong [trâm $h \quad n g$ ] (in French calembouc) is almost as resinous but contains more wood and is therefore lighter and harder than $k y$ nam and sinks in water; and (3) thie hieong [tiên $b \quad n g]$ described as "eaglewood proper" is whiter and less resinous than the previous two grades (Cordier 1887; Li 1998). Poivre further describes four nonresinous grades of agarwood (called sin-, lao-, nhil-, and nhi-bieong) that are nonfragrant and often used to adulterate consignments of the three commercial grades. He suggested that one has to be a connoisseur to purchase agarwood, due to widespread and skillful counterfeiting, which is undertaken by blackening the nonresinous agarwood by coating it with a foreign resin and embalming with the smoke of genuine agarwood (Cordier 1887).

\section{Contemporary Use}

Agarwood continues to be an important part of spiritual and secular life for many cultures where it has been used traditionally. In contemporary Middle Eastern and Asian consumer markets, agarwood pieces with high resin content will be burnt directly without any processing or addition of other fragrances. 
Agarwood with lower concentration of resin is often blended with other fragrant ingredients to create composite incense products (Garcia 2015). Incense rituals (kōdō) are still practised widely in Japan today with blends being categorized by one of two key base ingredients: agarwood or sandalwood (Moeran 2009). In many Middle Eastern societies, agarwood is used as a sign of wealth and status particularly during religious rites and social occasions and to infuse personal and domestic items with its distinct fragrance (Antonopoulou et al. 2010; Jung 2011).

The oil extracted from agarwood remains an important fragrant product in traditional consumer countries and demand in emerging niche markets in "western" countries is increasing. Agarwood oil is one of the five most important ingredients in Chinese perfumery (Yunjun 2013), an important element of Arabian perfumes (Marian [Olfatory Rescue Service blog contributor] 2011) and becoming prominent in the modern western fragrance industry (Burn-Callander 2015; Osborne 2014). The oil is typically extracted from agarwood with low oil concentration by the process of distillation. It is often used as a prominent base note for perfumes owing to its rich aroma, low volatility, and extended longevity of fragrance (Lias et al. 2016).

An increasing global demand for agarwood over recent decades can be attributed partly to increasing population and wealth in several consumer countries (Wyn and Anak 2010). Increased demand has stimulated price rises for all agarwood products, making them even more exclusive. This has led to an increase in product adulteration and substitution (Hashim et al. 2016; Lias et al. 2016) and more intense and illegal harvesting of wild stands and depletion of important natural agarwood resources (Soehartono and Newton 2002; Wyn and Anak 2010; Yin et al. 2016; Zhang et al. 2008). According to the IUCN Red List Criteria, seven Aquilaria species are classified as vulnerable ( $A$. banaensis P.H. Hô., A. beccariana Tiegh, A. cumingiana (Decne.) Ridl., A. hirta Ridl., A. malaccensis Lam., A. microcarpa Baill., and $A$. sinensis (Lour.) Spreng.) and face "a high risk of extinction in the wild in the medium-term future." The species $A$. crassna and $A$. rostrata $\mathrm{Ridl}$. were classified as being critically endangered with "an extremely high risk of extinction in the wild in the immediate future."

In recognition of the dwindling state of agarwood resources (Newton and Soehartono 2001), the Convention on International Trade of Endangered Species (CITES) included all producing agarwood species (not only Aquilaria genus) in Appendix II (CITES 2017). Species listed in Appendix II are "not necessarily ... .threatened with extinction [but] may become so unless their trade . . is subject to strict regulation in order to avoid utilization incompatible with their survival" (CITES 2017). The high prices paid for agarwood products have stimulated activity in the cultivation of the tree (Hoang $\mathrm{Ha}$ and Nghi 2011) and renewed interest in artificial stimulation of agarwood formation (Liu et al. 2013; Rasool and Mohamed 2016; Zhang et al. 2012). These initiatives are considered to potentially create alternative sources of agarwood and increase the availability of agarwood product in the marketplace (Nakashima et al. 2005; Persoon 2008).

\section{Conclusions}

Agarwood follows a long tradition of use in both spiritual and secular applications and has been synonymous with luxury, exclusivity, and intimacy. Recorded use of agarwood dates back to at least c 1400 B.C.E. and continued throughout human history including references in many seminal religious texts (Mahābhārata, Holy Bible, Jātaka, and several Hadith), treatise, poetry, pharmacopeia, floras, and trade texts. In the ancient epic Hindu text The Mahābhārata, agarwood was referenced as a welcome offering and also had a prominent place as a luxury item and status symbol. In the Holy Bible, the spiritual significance of agarwood was demonstrated when it was used with myrrh in the anointing of Jesus Christ following his crucifixion. The spiritual importance of agarwood in Buddhism was similarly demonstrated when it was used among other fragrant products in the cremation of Tathägata (Buddha). Agarwood was also cited three times in the Holy Bible as a fragrant product for intimacy and seduction. In Islamic texts, agarwood was a conspicuous fragrance used in the ritual burning of incense, for spiritual purification, and as one of the rewards in Paradise. Agarwood mixed with camphor was the preferred scent of the Prophet Muhammad. The citation of agarwood in many eminent religious texts confirms its reputation as an important product supporting spirituality.

The long historical use of agarwood has been associated with cultures where aromatics are deeply ingrained in cultural experience, such as the Middle East, India, China, and Japan. Among the many available plant-based aromatics, agarwood has always been considered to be among the most 
respected for its use as the basis of incense, perfumes, other fragrant products, and medical preparations. The medical use of agarwood has been recorded in Greek and Roman, Chinese, Middle Eastern, and European literature. It is not unusual to find agarwood included in the long lists of valuable items as offerings to important people or tribute to other nations. The popularity of the agarwood aroma has been consistent throughout history and continues to remain in high demand today for use in traditional and contemporary incense and perfumes.

\section{Acknowledgements}

A.L-S. was a recipient of an Australia Award Postgraduate Scholarship (AusAID). K Fowler provided assistance with literature searching. L Liddy translated the Latin text of classic texts. JC Doran and R. Burns provided constructive comments on the manuscript.

Open Access This article is distributed under the terms of the Creative Commons Attribution 4.0 International License (ht t p:// creativecommons.org/licenses/by/4.0/), which permits unrestricted use, distribution, and reproduction in any medium, provided you give appropriate credit to the original author(s) and the source, provide a link to the Creative Commons license, and indicate if changes were made.

\section{Literature Cited}

Ali, D. 2011. Rethinking the history of the kāma world in early India. Journal of Indian Philosophy 39(1): 1-13.

Allami, A.F. 1873. Ain-i-Akbari. Translated from the original Persian by H. Blochmann, vol. 1. Calcutta: Asiatic Society of Bengal.

—. 1891. Ain-i-Akbari (1590). Translated from the original Persian by H.S. Jarrett, vol. 2. Calcutta: Asiatic Society of Bengal.

Antonopoulou, M., J. Compton, L.S. Perry and R. Al-Mubarak. 2010. The trade and use of agarwood (oudh) in the United Arab Emirates. Petaling Jaya, Selangor, Malaysia, TRAFFIC Southeast Asia. http://www.traffic.org/speciesreports/traffic_species_plants16.pdf

Aston, W.G. 1896. Nihongi: Chronicles of Japan from the earliest times to A.D. 697, translated from the original Chinese and Japanese by W.G.
Aston. London: Kegan Paul, Trench, Trubner \& Co.

Atikal, I. 1994. The tale of an Anklet: An epic of South India, Translated by R. Pathasarathy. New York: Columbia University Press.

Balfour, J.H. 1866. The plants of the Bible. London: T. Nelson \& Sons.

Banerjee, G. 1921. Greece and Rome. In: India as known to the ancient world. 15-29, London: Oxford University Press.

Bansal, S.P. 2006. On the footsteps of the Buddha. New Delhi: Smiriti Books.

Barden, A., N.A. Anak, T. Mulliken and M. Song. 2000. Heart of the matter: Agarwood use and trade and CITES implementation for Aquilaria malaccensis. Cambridge, UK, TRAFFIC. https://www.traffic.org/forestry-reports/traffic_ pub_forestry7.pdf

Baumann, B.B. 1960. The botanical aspects of ancient Egyptian embalming and burial. Economic Botany 14(1): 84-104.

Bazin, N. 2013. Fragrant ritual offerings in the art of Tibetan Buddhism. Journal of the Royal Asiatic Society 23(1): 31-38.

Bedini, S.A. 1963. The scent of time. A study of the use of fire and incense for the time measurement in oriental countries. Transactions of the American Philosphical Society 53(5): 1-51.

. 1994. The trail of time: Time measurement with incense in East Asia (Shih-chien ti tsu-chi). Cambridge, UK: Cambridge University Press.

Bloomfield, M. 1897. Hymns of Atharva Veda, translated by M. Bloomfield. Oxford, UK: Clarendon Press.

Borris, R.P., G. Blaskó and G.A. Cordell. 1988. Ethnopharmacologic and phytochemical studies of the Thymelaeaceae. Journal of Ethnopharmacology 24(1): 41-91.

Bose, S.R. 1938. The nature of "agaru" formation. Science and Culture 4(2): 89-91.

Brechbill, G.O. 2012. The woody notes of fragrance. New Jersey, USA: Fragrance Book Inc.

Brinkley, C.F. 1902. Japan: Its history arts and literature, vol. 3. London: J.B. Millet Company.

Browning, W.R.F. 2010. Aloes. In: A dictionary of the Bible 2nd, Oxford, UK: Oxford University Press.

Bruce, J. 1810. Annals of the honorable East India Company from their establishment by the charter of Queen Elizabeth, 1600, to the union of the London and English East-India Companies, 
1707-8, volumes 1 to 3. London: Black, Parry \& Kingsbury.

Burn-Callander, R. 2015. Roja Dove, 'the nose': On creating a Western aoud cult. The Telegraph (London) 15 May 2015.

Chakrabarty, K., A. Kumar and V. Menon. 1994. Trade in agarwood. New Delhi: TRAFFIC India. http://www.traffic.org/forestry-reports/traffic_pub_forestry20.pdf.

Chaudhuri, K.N. 1978. The trading world of Asia and the English East India Company 16601760. Cambridge, UK: Cambridge University Press.

. 1985. Trade and civilisation in the Indian Ocean: An economic history from the rise of Islam to 1750 . Cambridge, UK: Cambridge University Press.

Chin-keong, N. 2017. Boundaries and beyond: China's maritime southeast in late imperial times. Singapore: NUS Press.

CITES. 2017. Appendices I, II and III valid from 4 October 2017. https://cites.org/sites/default/ files/eng/app/2017/E-Appendices-2017-10-04. pdf. Accessed: 25/10/2017.

Classen, C., D. Howes and S. A. 1994. Aroma: The cultural history of smell. London: Routledge.

Cobb, M.A. 2013. The reception and consumption of eastern goods in Roman society. Greece and Rome 60(1): 136-152.

Compton, J. and A. Ishihara. 2006. The use and trade of agarwood in Japan. Southeast Asia and East Asia-Japan, TRAFFIC. http://144.76.93. 178/sites/default/files/common/com/pc/15/XPC15-06-Inf.pdf

Constable, O.R. 1994. Trade and traders in muslim Spain. Cambridge, UK: Cambridge University Press.

Cordier, H. 1887. Journal d'un voyage à la Cochinchine depuis le 29 Aoust 1749, jour de notre arrivée, jusqu'au 11 Février 1750. Revue de l'Extrême-Orient, tome 3: 81-12.

Counts, D.B. 1996. Regum externorum consuetudine: The nature and function of embalming in Rome. Classical Antiquity 15(2): 189-202.

Cowell, E.B. 1907. The Jàtaka or stories of the Buddha's former births. Cambridge, UK: Cambridge University Press.

Cowell, E.B. and F.W. Thomas. 1887. The Harshacharita of Banabhatta translated by E.B. Cowell and F.W. Thomas. London: Royal Asiatic Society.
Crosswhite, F.S. and C.D. Crosswhite. 1984. Aloe vera, plant symbolism and the threshing floor. Desert Plants 6(1): 43-50.

CSIR (India). 1953. The wealth of India: A dictionary of Indian raw materials and industrial products, part 3. Delhi, India: Council of Scientific and Industrial Research.

Dannaway, F.R. 2010. Strange fires, weird smokes and psychoactive combustibles: Entheogens and incense in ancient traditions. Journal of Psychoactive Drugs 42(4): 485-497.

de Orta, G. 1891. Coloquios dos simples e drogas da India. Lisboa: Imprensa Nacional.

Donovan, D. and R. Puri. 2004. Learning from traditional knowledge of non-timber forest products: Penan Benalui and the autecology of Aquilaria in Indonesian Borneo. Ecology and Society 9(3): 3.

Driscoll, J.F. 1953. Incense. In: The new SchaffHerzog encyclopedia of religious knowledge, volume v, eds. S.M. Jackson, C.C. Sherman and G.W. Gilmore, 468-471, Grand Rapids, MI: Baker Book House.

Ergin, N. 2014. The fragrance of the divine: Ottoman incense burners and their context. Art Bulletin xcvi(1):70-97.

Feener, R.M. and M.F. Laffan. 2005. Sufi scents across the Indian Ocean: Yemeni hagiography and the earliest history of Southeast Asian Islam. Archipel 70(1): 185-208.

Fitzgerald, C.P. 1961. China: A short cultural history, 3rd London, UK: The Cresset Press.

Flecker, M. 2001. A ninth-century AD Arab or Indian shipwreck in Indonesia: First evidence for direct trade with China. World Archaeology 32(3): 335-354.

Foltz, R. 2010. Religions of the Silk Road: Premodern patterns of globalization, 2nd New York: Palgrave Macmillan.

Freedman, P. 2008. Out of the East: Spices and the medieval imagination. New Haven, CT: Yale University Press.

Gannal, J.-N. 1840. History of embalming and of preparations in anatomy, pathology, and natural history; including an account of a new process for embalming. Translanted from the French, with notes and additions R. Harlan. Philadelphia, PA: J. Dobson.

Garcia, B. 2015. Bukhoor: Not just a perfume, but a sweet fragrance of culture, hospitality and healing. Kuwait Times, 17 July 2015. Safat. 
Gatten, A. 1977. A wisp of smoke: Scent and character in the tale of Genji. Monumenta Nipponica 32(1): 35-48.

Giovannucci, D. and T. Reardon. 2000. Understanding grades and standards and how to apply them. St. Louis, MO: Federal Reserve Bank of St Louis.

Greppin, J.A.C. 1988. The various aloës in ancient times. The Journal of Indo-European Studies 16(1-2): 33-48.

Griffith, R.T.H. 1897. The hymns of the Rig Veda. English translation by R.T.H. Griffith. vol. 2. Benares: E.J. Lazarus.

Grindlay, D. and T. Reynolds. 1986. The Aloe vera phenomenon: A review of the properties and modern uses of the leaf parenchyma gel. Journal of Ethnopharmacology 16(1-2): 117-151.

Groom, N. 1981. Frankincense and myrrh: A study of the Arabian incense trade. London: Longman.

Gungwu, W. 1958. The Nanhai trade: A study of the early history of Chinese trade in the South China Sea. Journal of the Malayan Branch of the Royal Asiatic Society 31(182): 1-135.

Gunn, B., P. Steven, S. Margaret, L. Sunari and P. Chatterton. 2004. Eaglewood in Papua New Guinea (Resource Management in Asia-Pacific Working Paper no. 51). Canberra, ANU. https://openresearch-repository.anu.edu.au/ bitstream/1885/39956/2/2532-01.2004-0503T05:44:55Z.xsh

Haq, Z. 1968. Inter-regional and international trade in pre-islamic Arabia. Islamic Studies 7(3): 207-232.

Harbaugh, H. 1855. The trees of the bible: VIIAloe. The Guardian: A monthly magazine vi(v): 153-154.

Harris, J.A. 1744. Navigantium atque itinerantium bibliotheca: A complete collection of voyages and travels consisting of above six hundred of the most authentic writers volume 2. London: T. Woodard \& Co.

Hashim, Y.Z.H.Y., P.G. Kerr, P. Abbas and H.M. Salleh. 2016. Aquilaria spp. (agarwood) as source of health beneficial compounds: A review of traditional use, phytochemistry and pharmacology. Journal of Ethnopharmacology 189: 331-360.

Heldaas Seland, E. 2011. The Persian Gulf or the Red Sea? Two axes in ancient Indian Ocean trade, where to go and why. World Archaeology 43(3): 398-409.

Hoang Ha, Q. and H.T. Nghi. 2011. Promoting agarwood-based agroforestry systems in north central provinces of Viet Nam. Asia-Pacific Agroforestry Newsletter 38(38): 10-12.

Hou, D. 1960. Thymelaeaceae, In: Flora malesiana, ed. C.G.G.J. Van Steenis, 1-48, Groningen, The Netherlands: Wolters-Noordhoff Publishing.

- 1964. Notes on some Asiatic species of Aquilaria (Thymelaeaceae). Blumea 12(2): 285288.

Hourani, G.F. 1951. Arab seafaring in the Indian Ocean in ancient and early medieval times. Princeton, NJ: Princeton University Press.

Howes, F.N. 1950. Age-old resins of the Mediterranean region and their uses. Economic Botany 4(4): 307-316.

Hull, B.Z. 2008. Frankincense, myrrh, and spices. The oldest global supply chain? Journal of Macromarketing 28(3): 275-288.

Indicopleustes, C. 1897. The Christian topography of Cosmas, an Egyptian monk. Translated from the Greek, and edited with notes and introduction by J.W. McCrindle. London, Hakluyt Society.

Ireland, J.D. 2005. Sesavati's mansion: Vv 3.7 PTS: Vv 647-658. Pali text edited and translated by J.D. Ireland. https://www.accesstoinsight.org/ tipitaka/kn/vv/vv.3.07.irel.html.

Islam, A. 2010. Arab navigation in the Indian ocean before European dominance in South and Southeast Asia: A historical study. Journal of the Friends' Historical Society lviii(2): $7-23$.

Ismail, N., M.H.F. Rahiman, M.N. Taib, M. Ibrahim, S. Zareen and S.N. Tajuddin. 2015. A review on agarwood and its quality determination. In: 2015 I.E. 6th Control and System Graduate Research Colloquium (ICSGRC), 103-108. Shah Alam, Malaysia: IEEE Xplore Digital Library.

Iyengar, R.N. 2003. Internal consistency of eclipses and planetary positions in Mahābhārata. Indian Journal of History of Science 38(2): 77-115.

Ju-Kua, C. (1911). Chau Ju-Kua: His work on the Chinese and Arab trade in the twelfth and thirteenth centuries, entitled Chu-fan-chi. Translated from Chinese and annotated by F. Hirth, and W.W. Rockhill. St. Petersberg: Imperial Academy of Sciences.

Jung, D. 2011. The value of agarwood. Reflections upon its use and history in South Yemen. In: Workshop proceedings: The use of herbs in Yemeni healing practices. September 25-26, 2009. Halle, Germany: HeiDOK. 
Kahl, O. 2011. The pharmacological tables of Rhazes. Journal of Semitic Studies 56(2): 367399.

Kearney, M. 2004. The Indian Ocean in world history. New York: Routledge.

Keay, J. 2006. The spice route: A history. Los Angeles, CA: University of California Press.

Keith, A.B. 1914. The Veda of the Black Yajus school entitled Taittiriya sanhita (the Yajur Veda), translated by Arthur Berriedale Keith. Cambridge, MA, Harvard University Press. https:// www.ignaciodarnaude.com/espiritualismo/ Vedas, Yajur\%20Veda.pdf

King, A. 2007. The musk trade and the Near East in the early medieval period. (Doctor of Philosophy dissertation), University of Indiana, Bloomington, IN.

2015. The new materia medica of the Islamicate tradition: The pre-Islamic context. Journal of the American Oriental Society 135(3): 499-528.

Koller, J., U. Baumer, Y. Kaup, H. Etspüler and U. Weser. 1998. Embalming was used in Old Kingdom. Nature 39(6665): 343-344.

Kubeczka, K.-H. 2016. History and sources of essential oil research. In: Handbook of essential oils science, technology and applications, eds. K.H.C. Baser and G. Buchbauer, Boca Raton, FL: CRC Press.

Lach, D.F. 1905. Asia in the marketing of Europe, vol. 1, book 2. Chicago: The University of Chicago Press.

Lanciani, R. 1892. Pagan and Christian Rome. Cambridge, UK: The Riverside Press.

Lardos, A., J. Prieto-Garcia and M. Heinrich. 2011. Resins and gums in historical iatrosophia texts from Cyprus-A botanical and medicopharmacological approach. Frontiers in Pharmacology 2(32): 1-26.

Leidy, D.P. and D.K. Strahan. 2010. Wisdom embodied: Chinese, Buddhist and Daoist sculpture in the Metropolitan Museum of Art. New York: Metropolitan Museum of Art.

Levey, M. 1961. Ibn Mäsawaih and his treatise on simple aromatic substances: Studies in the history of arabic pharmacology I. Journal of the History of Medicine and Allied Sciences 16(4): 394-410.

Li, T. 1998. Nguyen Cochinchina: Southern Vietnam in the seventeenth and eighteenth centuries Ithaca, New York: Southeast Asia Program Publications, Cornell University.
Lias, S., N.A.M. Ali, M. Jamil, A.M. Jalil and M.F. Othman. (2016). Discrimination of pure and mixture agarwood oils via electronic nose coupled with k-NN kfold classifier. In: 11th Asian conference on chemical sensors 20, eds. Noor, M., A.Y.M. Shakaff, A.H. Adom, N. Miura, C.W. Lin, A. Zakaria, A. Tuantranont, S.K. ZaAba, R. Ngadiran, W.Y. Chung, A. Harun, S.M. Mamduh, N. VanHieu, L.M. Kamarudin, N.A.H. Zahri and S. Zakaria, 6368, Amsterdam: Elsevier Science.

Liebig, M. 2014. Kauțilya’s Arthaśāstra: A classic text of statecraft and an untapped political science resource. Heidelberg Papers in South Asian and Comparative Politics: Working Paper, 74. http://archiv.ub.uni-heidelberg.de/ volltextserver/17144/2/Heidelberg\%20Papers_ 74_Liebig_revised.pdf

Liu, X. 1994. Ancient India and ancient China: Trade and religious exchanges, AD 1-600 Delhi: Oxford University Press.

- 2010. The Silk Road in world history. New York: Oxford University Press.

Liu, Y., H. Chen, Y. Yang, Z. Zhang, J. Wei, H. Meng, W. Chen, J. Feng, B. Gan, X. Chen, Z. Gao, J. Huang, B. Chen and H. Chen. 2013. Whole-tree agarwood-inducing technique: An efficient novel technique for producing highquality agarwood in cultivated Aquilaria sinensis trees. Molecules 18(3): 3086-3106.

Lucas, A. 1930. Cosmetics, perfumes and incense in ancient Egypt. The Journal of Egyptian Archeology 16(1/2): 41-53.

Lucas, S.C. 2008. Major topics of the hadith. Religion Compass 2(2): 226-239.

Marian [Olfatory Rescue Service blog contributor]. 2011. Top ten mukhallats (Arabian perfume oil). October 25, 2011. https://olfactoryrescueservice. wordpress.com/2011/10/25/top-tenmukhallats/. Accessed: 12 November 2015.

Masudi, H. 1877. Les prairies d'or. Translated in 1861 by C. Barbier de Meynard and Abel Pavet de Courteille. Paris: A L'Imprimerie Impériale.

Mathews, R.H. 1974. Chinese-English dictionary (A Chinese-English dictionary compiled for the China Inland Mission). Cambridge, MA: Harvard University Press.

Matthioli, P.A. 1554. Sinensis medici: Commentarii in sex libros Pedacii Dioscoridis Anazarbei de materia medica. [With the Latin version of the text of Dioscorides by J. Ruellius]. Balthasard Arnoullet. 
McClintock, J. and J. Strong. 1867. Cyclopaedia of biblical theological and ecclesiastical literature, volume 1. New York: Harper \& Brothers Publishers.

McHugh, J. 2011. The incense trees of the land of emeralds: The exotic material culture of Kāmaśāstra. Journal of Indian Philosophy 39(1): 63-100.

. 2012. Sandalwood and carrion: Smell in Indian religion and culture. Oxford, UK: Oxford University Press.

McKenna, D.J. and K. Hughes. 2014. The incense bible: Plant scents that transcend world culture, medicine, and spirituality. New York: Routledge.

McLaughlin, R. 2008. Silk ties: The links between ancient Rome \& China. History Today 58(1): 34-41.

Miller, J.I. 1969. The spice trade of the Roman Empire. Oxford, UK: Oxford University Press.

Moeran, B. 2009. Making scents of smell: Manufacturing and consuming incense in Japan. Human Organization 68(4): 439-449.

Mohamed, R. and S.Y. Lee, 2016a. Agarwood: Science behind the fragrance. Singapore: Springer.

_- _ 2016b. Keeping up appearances: Agarwood grades and quality. In: Agarwood: Science behind the fragrance, ed. Rozi Mohamed, 149-167, Singapore: Springer.

Mohamed, R., P.L. Jong and A.K. Kamziah. 2014. Fungal inoculation induces agarwood in young Aquilaria malaccensis trees in the nursery. Journal of Forestry Research 25(1): 201-204.

Morita, K. 1992. The book of incense: Enjoying the traditional art of Japanese scents. Tokyo: Kodansha International.

Morris, E.T. 1984. Fragrance: The story of perfume from Cleopatra to Chanel. New York: Charles Scribner's Sons.

Sahih Muslim. n.d.. Collection of sunnah and hadith. http://www.usc.edu/org/cmje/religioustexts/hadith/. Accessed: 19 February 2016.

Nakashima, E.M.N., M.T.T. Nguyen, Q.L. Tran and S. Kadota. 2005. Field survey of agarwood cultivation at Phu Quoc Island in Vietnam. Journal of Traditional Medicines 22(5): 296300.

Newton, A.C. and T. Soehartono. 2001. CITES and the conservation of tree species: The case of Aquilaria in Indonesia. International Forestry Review 3(1): 27-33.
Ng, L.T., Y.S. Chang and A.A. Kadir. 1997. A review on agar (gaharu) producing Aquilaria species. Journal of Tropical Forest Products 2(2): 272-285.

Nunnamaker, A.J. and C.O. Dhonau. 2015. Anatomy and embalming: A treatise on the science and art of embalming: The latest and most successful methods of treatment and the general anatomy relating to this subject. Istanbul: eKitap Projesi.

Osborne, L. 2014. In the mood for oud? Town and Country, vol. 126. New York: Hearst Magazines, a Division of Hearst Communications, Inc.

Page, T. and W. Awarau. 2012. Performance of agarwood (Aquilaria crassna) seedling transplants improved by shade and fertiliser. Forest Ecology and Management 265: 258-269.

Paoli, G.D., D.R. Peart, M. Leighton and I. Samsoedin. 2001. An ecological and economic assessment of the nontimber forest product gaharu wood in Gunung Palung National Park, West Kalimantan, Indonesia. Conservation Biology 15(6): 1721-1732.

Papageorgopoulou, C., N. Shved, J. Wanek and F.J. Ruhli. 2015. Modeling ancient Egyptian mummification on fresh human tissue: Macroscopic and histological aspects. Anatomical Record-Advances in Integrative Anatomy and Evolutionary Biology 298(6): 974-987.

Parker, G. 2008. The making of Roman India. Cambridge, UK: Cambridge University Press.

Peacock, D.P.S., A.C.S. Peacock and D. Williams. 2006. Food for the gods: New light on the ancient incense trade. Oxford, UK: Oxbow Books.

Penchala, P.G., M. Neelima and V. Pammi Satyanrayanashastry. 2008. Historical perspectives on the usage of perfumes and scented articles in ancient Indian literatures. Ancient Science of Life 28(2): 33-39.

Persoon, G.A. 2008. Growing 'the wood of the gods': Agarwood production in Southeast Asia. In: Smallholder tree growing for rural development and environmental services: Lessons from Asia, vol. 5, eds. D. J. Snelder and R. D. Lasco, 245-262, Dordrecht, Netherlands: Springer.

Pierce, D.C. 1969. The middle way of the Jātaka tales. The Journal of American Folklore 82(325): 245-254.

Pires, T. 1944. The suma oriental of Tome Pires: An account of the East, from the Red Sea to China, written in Malacca and India in 1512-1515. 
Translated from the Portuguese MS in the Bibliothèque de la Chambre des Députés, Paris, ed. A. Cortesao, vol. 1. London: Hakluyt Society.

Prasad, P.C. 1977. Foreign trade and commerce in ancient India. New Delhi: Abhinav Publications.

Prinsep, J. 1834. Useful tables, forming an appendix to the Journal of the Asiatic Society: Part the first, coins, weights, and measures of British India. Calcutta: Baptist Mission Press.

Rahman, M., N.M. Nath, S. Sarker, M. Adnan and M. Islam. 2015. Management and economic aspects of growing Aquilaria agallocha Roxb. in Bangladesh. Small-Scale Forestry 14(4): 459478.

Rasool, S. and R. Mohamed. 2016. Understanding agarwood formation and its challenges. In: Agarwood: Science behind the fragrance, ed. R. Mohamed, 39-56, Singapore: Springer.

Rhind, J.P. 2014. Fragrance and wellbeing: Plant aromatics and their influence on the psyche. London: Singing Dragon.

Rimmel, E. 1865. The book of perfumes. London: Chapman and Hall.

Samaddar, J.N. 1911. Ancient India's commercial relations. Journal of the Royal Society of Arts 59 (3064): 903-909.

Sandison, A.T. 1963. The use of natron in mummification in ancient Egypt. Journal of Near Eastern Studies 22(4): 259-267.

Sangareswari, M., K.T. Parthiban, S.U. Kanna, L. Karthiba and D. Saravanakumar. 2016. Fungal microbes associated with agarwood formation. American Journal of Plant Sciences 7: 14451452.

Schafer, E.H. 1963. The golden peaches of Samarkand. Berkeley, CA: University of California Press.

Schoff, W.H. 1922. Aloes. Journal of the American Oriental Society 42: 171-185.

Scott, S.P. 1932. The digest or pandects of Justinian. Cincinatti, OH: The Central Trust Company.

Shamasastry, R. 1915. Kautilya's Arthashastra. http://libarch.nmu.org.ua/bitstream/handle/ $\mathrm{G}$ e n o f o n d U A / 19273 / f2c8936431b9587a3448e1b3d8eff8e8.pdf?sequence $=1$

Shiro, M. 1998. Dai Viet and the South China Sea trade: From the 10th to the 15th century. Crossroads: An Interdisciplinary Journal of Southeast Asian Studies 12(1): 1-34.
Shizhen, L. 2003. Compendium of materia medica: Bencao gangmu. Beijing, China: Foreign Languages Press.

Smith, G.F. 1993. Familial orthography-Aloeaceae vs Aloaceae. Taxon 42(1): 87-90.

Smith, G.F. and E.M.A. Steyn. 2004. Taxonomy of Aloaceae. In: The genus Aloe, ed. T. Reynolds, 14-35, Boca Raton, FL: CRC Press.

Smith, F.P. and G.A. Stuart. 2003. Chinese medicinal herbs: A modern edition of a classic sixteenth-century manual. Mineola, NY: Dover Publications.

Soehartono, T. and A.C. Newton. 2002. The gaharu trade in Indonesia: Is it sustainable? Economic Botany 56(3): 271-284.

Stargardt, J. 2001. Behind the shadows: Archaeological data on two-way sea trade between Quanzhou and Satingpra, South Thailand, 10th-14th Century. In: The emporium of the world: Maritime Quanzhou, 1000-1400, ed. A. Schottenhammer, 309-394, Leiden, Netherlands: Brill.

. 2014. Indian Ocean trade in the ninth and tenth centuries: Demand, distance, and profit. South Asian Studies 30(1): 35-55.

Strabo. 1930. Strabo geography H. L. Jones, trans., vol. viii. Cambridge, MA: Loeb Classical Library.

Thurkill, M.F. 2009. Odors of sanctity: Distinctions of the holy in early Christianity and Islam. Comparative Islamic Studies 3(2): 133-144.

Tielel, P.A. 1885. The Voyage of John Huyghen van Linschoten to the East Indies. From the old English translation of 1598, W. Phillip, translator. London: Whiting \& Co.

Turner, J. 2004. Spice: The history of a temptation. New York: Vintage Books.

Unschuld, P.U. and Z. Zhang. 2014. Dictionary of the ben cao gang mu, volume 1: Chinese historical illness terminology. Berkeley, CA: University of California Press.

Villiers, J. 2001. Great plenty of almug trees: The trade in southeast Asian aromatic woods in the Indian Ocean and China, 500 BC - AD 1500. The Great Circle 23(2): 24-43.

Warmington, E.H. 1928. The commerce between the Roman Empire and India. Cambridge, UK: Cambridge University Press.

1974. The commerce between the Roman Empire and India, 2nd ed. London: Curzon Press Ltd.

Watson, A. 1985. The digest of Justinian. Philadelphia, PA: University of Pennsylvania Press. 
Webber, H. 1812. Tales of the East, vol 1: Containing the Arabian nights and new Arabian nights' entertainments. Edinburgh, UK: John Ballantyne and Co.

Whelan, C. 2014. Kansai cool: A journey into the cultural heartland of Japan. Singapore: Tuttle Publishing.

Worwood, V.A. 2013. The fragrant heavens: The spiritual dimensions of fragrance and aromatherapy. London: Random House.

Wyn, L.T. and N.A. Anak. 2010. Wood for the trees: A review of the agarwood (gaharu) trade in Malaysia. Petaling Jaya, Selangor, Malaysia: TRAFFIC Southeast Asia.

Yin, Y., L. Jiao, M. Dong, X. Jiang and S. Zhang. 2016. Wood resources, identification, and utilization of agarwood in China. In: Agarwood: Science behind the fragrance, ed. Rozi Mohamed, 21-38, Singapore: Springer.

Yoshnobu, S. 1983. Sung foreign trade: Its scope and organization. In: China among equals: The Middle Kingdom and its neighbors, 10th to 14th century, ed. M. Rossabi, 89-115, Berkley, CA: University of California Press.

Yule, H. 1871. The book of Ser Marco Polo: Concerning the kings and marvels of the East, volume 2. London: John Murray, Albermarle Street.

Yule, H. and A.C. Burnell. 1903. Hobson-jobson: A glossary of colloquial Anglo-Indian words and phrases, and of kindred terms, etymological, historical, geographical and discursive. London: John Murray.
Yunjun, C. 2013. The perfume culture of China and Taiwan: A personal report. Journal of the Royal Asiatic Society (series three) 23(1): 127130.

Zhang, L., W.Y. Brockelman and M.A. Allen. 2008. Matrix analysis to evaluate sustainability: The tropical tree Aquilaria crassna, a heavily poached source of agarwood. Biological Conservation 141(6): 1676-1686.

Zhang, X.L., Y.Y. Liu, J.H. Wei, Y. Yang, Z. Zhang, J.Q. Huang, H.Q. Chen and Y.J. Liu. 2012. Production of high-quality agarwood in Aquilaria sinensis trees via whole-tree agarwoodinduction technology. Chinese Chemical Letters 23(6): 727-730.

Zohar, A. 2003. The ancient trade in incense, perfumes and spices. In: The Nabateans in the Negev (in Hebrew with English summary), ed. R. Rosenthal-Heginbottom, 61-66, Haifa: Hecht Museum.

Zohar, A. and E. Lev. 2013. Trends in the use of perfumes and incense in the Near East after the Muslim conquests. Journal of the Royal Asiatic Society 23(1): 11-30.

Zohary, M. 1982. Plants of the Bible. New York: Cambridge University Press.

Zumbroich, T.J. 2012. From mouth fresheners to erotic perfumes: The evolving socio-cultural significance of nutmeg, mace and cloves in South Asia. eJournal of Indian Medicine, 5, 37-97. http://rjh.ub.rug.nl/eJIM/article/view/24743/ 22193 